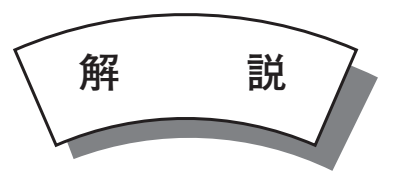

\title{
大気中電解質プラズマを用いた新機能性ナノバイオ物質創製
}

\section{Creation of Nanobio Materials Using Electrolyte Plasmas in the Atmosphere}

\author{
金子 俊 郎* ·李 永 峰* ・畠山力三* \\ Toshiro KANEKO, Yongfeng LI and Rikizo HATAKEYAMA
}

\begin{abstract}
Key Words: Electrolyte Plasma, Plasma Ion Irradiation Method, DNA Encapsulated Carbon Nanotube, Field Effect Transistor, Ionization Potential
\end{abstract}

\section{1. 緒言}

有機分子一つ一つに電子素子の役割を持たせようとする 「分子エレクトロニクスデバイス」が、現在注目を集めてお り、その構成要素として、DNAに代表される生体分子とフ ラーレンやカーボンナノチューブ等のナノカーボンを会合 させた新規ナノバイオ物質が有力な候補の一つとなってい る。DNAは 4 種類の塩基分子から構成され、それぞれが固 有の電子状態を持っているため、塩基配列によって様々な バンドギャップを持つ半導体になり得ることや ${ }^{1), 2) 、 D N A ~}$ をテンプレート (鋳型) として用いて金属微粒子を特定の 位置に配置することで、ナノ細線や量子ドット等の量子効 果を利用した新規デバイスも期待できることから、ユニー クな 1 次元系新機能性材料として盛んに研究が行われてい る ${ }^{3)}$ 。

一方、DNA の直径と同程度の内直径を持ち、炭素原子 のみからなる 1 次元系物質のカーボンナノチューブ (CNT) も、その特異な機械的、電気的、光学的特性から、超高速、 超低消費電力素子等への応用が期待されており、さらに DNA と相互作用させることにより、CNTを介してDNAの 電子状態の変化を観測する高感度のバイオセンサとしての 応 用 ${ }^{4)}$ やDNA を量子ドットとして動作させる量子効果デ バイスへの応用 ${ }^{5}$ 等も模索されている。しかしながら、こ れらのDNA は全て大気中に曝されており、構造的な脆弱 性を有するDNA は、外界からの影響で容易に欠陷、湾曲、 交錯などが起こり、これらの構造変化により電気的特性が 大きく変化するなど、デバイス化には多くの課題が残され ていた。

そこで本研究では、「プラズマ理工学的手法」を用いて DNA をCNT の内部空間に包み込むことで、CNTの機械的 強度、化学的安定性によりDNAの構造的な脆弱性を克服 でき、初めて安定な「分子エレクトロニクスデバイス」が 可能になると考え、新機能性材料として高いポテンシャル
を有する DNA 内包 CNT 等の新規ナノバイオ物質の創製を 目指している。

\section{2. 電解質プラズマイオン照射法}

これまで本研究室では、CNT 内部へ様々な原子・分子を 注入する手法として、これらをプラズマ化（イオン化）し、 プラズマ中に形成した電場による静電的な力を用いて内包 させる“プラズマイオン照射法”を独自に開発してきた ${ }^{6}$ 。 具体的には例えば、アルカリ金属正イオンとフラーレン負 イオンから成るプラズマを生成し ${ }^{7)}$, 8 、プラズマ中に導入 した CNT 塗布基板に印加するバイアスの極性・大きさを変 化させることで、アルカリ金属 ${ }^{9)}{ }^{10)}$ やフラーレン ${ }^{11)}$ を区別 して CNTへ内包する手法である。すなわち、正バイアスを 印加した場合には、フラーレン負イオンのみが CNT 基板に 照射される。このとき、CNT はフラーレン負イオンの衝突 エネルギーによって構造変形を起こし、その開端部からフ ラーレンが内包すると考えられている。一方、基板へのバ イアスを負にすれば、正イオンであるアルカリ金属が CNT に照射・内包される。

このように CNT 内部空間へ異種原子・分子を区別して 内包させるためには、プラズマ化（イオン化）することが 必須であるが、多くの機能を備えることが可能な分子性物 質（高分子等）は、一般にプラズマが生成される減圧下の 気相中ではイオン化することが困難である。しかしながら、 それらは大気圧下の溶液中においては容易にイオンとして 存在し、中でもDNA は溶液中において分子内に存在する リン酸基のため多価負イオンとして存在することが分かっ ている。このようなイオンを含む溶液は一般に電解質溶液 と呼ばれ、1920 年代に電解質溶液のイオン挙動に関して Debye と Huckelによって理論が構築され ${ }^{12)}$ 、気体プラズマ 理論へ発展した歴史的経緯がある。電解質溶液中のイオン は、気体プラズマと同様に電場を印加することでその挙動 を制御することが可能であるため、筆者らはこれらの電解

* 東北大学 大学院工学研究科 電子工学専攻（９ 980-8579 仙台市青葉区荒巻字青葉 6-6-05）

Department of Electronic Engineering, Tohoku University (6-6-05 Aoba, Aramaki, Aoba-ku, Sendai 980-8579, Japan) 
Table 1 Comparison between gas and electrolyte plasmas.

\begin{tabular}{|l|l|l|}
\hline & 気体プラズマ ${ }^{\mathrm{a}}$ & 電解質プラズマ ${ }^{\mathrm{b}}$ \\
\hline 構成種 & $\begin{array}{l}\text { 電子 } \\
\text { 正イオン } \\
\text { 中性粒子 }\end{array}$ & $\begin{array}{l}\text { 負イオン } \\
\text { 正イオン } \\
\text { 中性粒子 }\end{array}$ \\
\hline 電荷 & 準中性 & 準中性 \\
\hline 温度 $T$ & $\sim 3.0 \mathrm{eV}$ & $0.025 \mathrm{eV}(300 \mathrm{~K})$ \\
\hline 密度 $n$ & $\sim 10^{10} \mathrm{~cm}^{-3}$ & $\sim 10^{15} \mathrm{~cm}^{-3}$ \\
\hline デバイ長 $\lambda_{\mathrm{D}}$ & $\sim 0.13 \mathrm{~mm}$ & $\sim 11 \mathrm{~nm}$ \\
\hline
\end{tabular}

${ }^{\mathrm{a}}$ 典型的な直流放電プラズマの場合

${ }^{\mathrm{b}}$ DNA 濃度が $10^{-5} \mathrm{~mol} / \mathrm{l}$ の場合

質溶液を「電解質プラズマ」と定義し、気相プラズマと同 様に扱うことを提案している ${ }^{13)}$

ここで、電解質プラズマと気体プラズマとの比較を行っ てみた（表 1)。電解質プラズマは荷電粒子（電解質）と中 性粒子 (溶媒) から構成され準中性であることから、気体 プラズマと同様に扱うことができる。一方で電解質プラズ マは液体であるため、密度が非常に高く、温度が低いこと に起因して、デバイ長がナノメートルオーダーと極端に短 いことが特徴であり、また高密度であることから従来の気 体プラズマとは異なる物理的・化学的反応が期待でき、新 物質創製に大きな可能性を秘めていると考えることができ る。

以上の背景を基に本研究では、これまでに実績のある気 相プラズマ中での「プラズマイオン照射法」をDNA が負 イオンとして存在する溶液（電解質プラズマ）に適用する ことで、DNA を内包したカーボンナノチューブベースの新 機能性ナノバイオ物質を創製し、バイオ・ナノ科学融合の 革新的なナノスケール分子エレクトロニクスデバイスを実 現することを目的としている。

\section{3. 実験装置}

図 1 に電解質プラズマ実験装置図を示す。 $5 \mathrm{~cm}^{3}$ の DNA 水溶液中に $5 \mathrm{~mm} \times 40 \mathrm{~mm}$ のアルミニウム製アノード、及 びカソード電極を挿入し、直流電圧 $V_{\mathrm{DC}}$ 及び高周波電圧 $V_{\mathrm{RF}}$ を独立に印加する。アノード電極上には、炭素シート 1 枚 が筒状に丸まった直径 1 ～ $2 \mathrm{~nm}$ の単層カーボンナノチュー ブ $(\mathrm{SWNT})$ 及び炭素シート2枚で構成される直径 $3 \sim 5$ $\mathrm{nm}$ の二層カーボンナノチューブ (DWNT) を塗布してある。 DNA は溶液中で負イオンとして存在するため、直流電場を 印加することでアノードへの DNA 負イオン照射を行うこ とができる。また、高周波電場を印加すると、溶液中で糸 玉形状を呈しているDNA が分子内分極と高周波電場との 相互作用で伸長することがわかっているため ${ }^{14)}$ 、伸長した DNA を CNT に照射することでDNAの内包効率が向上す ることが期待できる。なお、直流電場を印加した場合には、

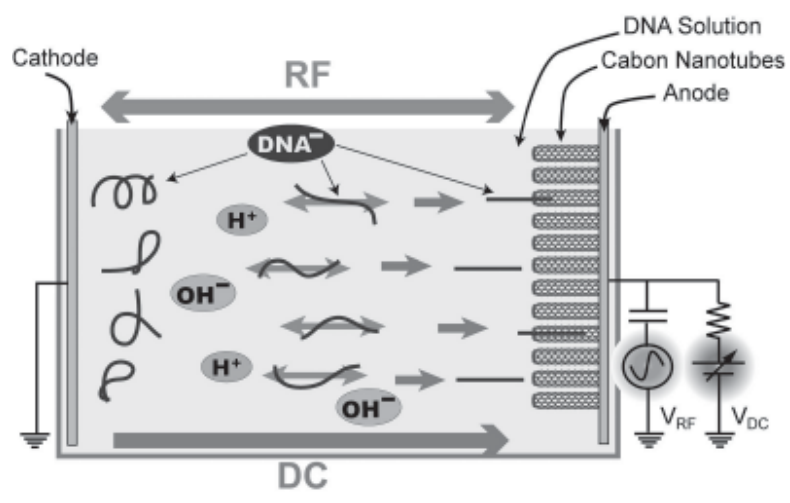

Fig. 1 Schematic of experimental apparatus.

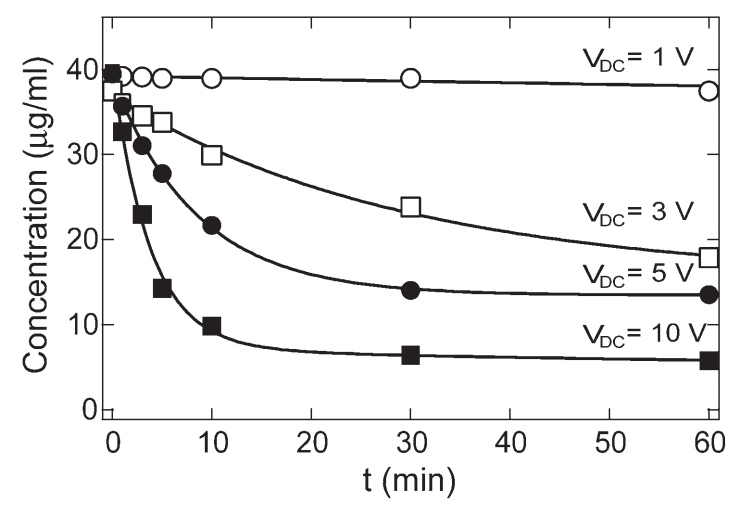

Fig. 2 Time evolution of concentration of the DNA electrolyte plasma.

シース電場の効果により CNT が電場に沿って配向するた め)、DNA と CNT の先端開口部は共に対峙した位置関係 になり、DNA が挿入されやすい状態になっている。

また電極に用いているアルミニウムは、DNA 分子への 表面活性が高い材料として知られているため、照射された DNA 負イオンはアノード電極表面に半永久的に吸着する。 従って、照射時間の経過と共に溶液濃度が減少することに なり、その減少量から DNA 負イオン照射量を見積ること が可能である。

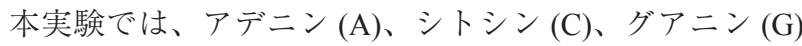
で構成される 1 重螺旋 DNA を用いており、1 本の DNA 内 に存在する塩基数 (鎖長) を添字 $\mathrm{x} て ゙ ~ \mathrm{~A}_{\mathrm{x}}$ のように表す。

\section{4. 実験結果と考察}

まずは、DNA 水溶液の濃度変化から基板への DNA 負イ オン照射量を算定するために、DNA 水溶液の波長 $260 \mathrm{~nm}$ 近傍の吸光スペクトルピーク変化を測定した。ここでは、 基板上に CNT は塗布していない。図 2 にNA 水溶液濃度 の直流電場印加時間 $t$ 依存性を示す。時間経過と共にDNA 水溶液濃度が減少しており、その減少量、すなわち基板へ の照射量は $V_{\mathrm{DC}}$ の増加と共に増加していることがわかる。 
これらの結果より、DNA 負イオン照射量は照射時間と $V_{\mathrm{DC}}$ で制御できることが明らかになった。また、このDNA 負 イオン照射量は、塩基の種類に依存しないことも明らかに なっている。

次に、基板上に SWNT を塗布し、印加する電場を変化さ せてDNA 負イオン照射を行い、その SWNTをラマン分光 法により解析した結果を図3(a)に示す。ここでは、SWNT の径方向の伸縮モードである Radial Breathing Mode (RBM) 領域に注目し、そのときのスペクトル形状の変化から DNA の内包について議論する。図中の “Pristine”は電場を印加 していない場合の結果である。“RF”は高周波電場のみを 印加していることを示しており、DNA 負イオンは溶液中 で伸長されているが能動的なイオン照射は行われていない ため、“Pristine”のスペクトルと比較して大きな変化は見 られない。一方、“DC”は直流電場のみを印加しているこ とを示しており、溶液中で糸玉形状を有しているDNA 負 イオンをその形状を維持して照射した結果である。この場 合には、図中点線で示した $164 \mathrm{~cm}^{-1}$ と $178 \mathrm{~cm}^{-1}$ の波数にお いてスペクトル強度の変化が観測されており、それぞれの ピーク強度の比 $\left(I_{\omega 164} / I_{\omega 178}\right)$ を算出することで [図 3(b) 参照]、“Pristine”との差異が明確にわかる。さらに“DC + RF” は、直流電場と高周波電場を重畳印加していること を示しており、この場合に $I_{\omega 164} / I_{\omega 178}$ の “Pristine”に対す る変化量が最も大きくなっていることがわかる。すなわち、 伸長されたDNA 負イオンを能動的に SWNT へ照射するこ とにより、DNA が SWNT 内部に効率よく内包されたこと を意味している ${ }^{15)}$ 。また、一定電場の条件下で、DNAの塩 基数を変化させることでもラマンスペクトルに変化が観測 され、内包効率に差異が生じることも明らかになっている ${ }^{6}$ 。

一方、DNA を構成する 4 種の塩基は異なる酸化電位を持 ち2)、アデニン、チミン、シトシンはそれぞれ 1.96、2.11、2.14 $\mathrm{V}$ である。これに対してグアニンは $1.49 \mathrm{~V}$ と低く、このこ とは他の塩基に対して電子ドナー性が高いことを示してい る。つまり、グアニンを含む DNA を用いることで DNA SWNT 間での電荷移動等の相互作用が期待できる。一般的 な SWNT のバンドギャップは〜 $1 \mathrm{eV}$ 程度 ${ }^{17)}$ であることか ら、これらの酸化電位がSWNT のバンドギャップに影響を 与えることは十分に可能である。

図 4 に、酸化電位の最も高いシトシン $\left(\mathrm{C}_{30}\right)$ と最も低いグ アニン $\left(\mathrm{G}_{30}\right)$ で構成される DNAを用い、DNA 負イオン照 射を行った SWNT のラマンスペクトルを示す。 $\mathrm{C}_{30}$ を照射 した場合（ $\mathrm{C}_{30} @ \mathrm{SWNT}$ ＠：内包を表わす）、164 $\mathrm{cm}^{-1}$ のピー クが Pristine の SWNT に比べて増大していることが分かる。 それに対して $\mathrm{G}_{30}$ を照射した場合には $\left(\mathrm{G}_{30} @ \mathrm{SWNT}\right) 、 \mathrm{C}_{30}$ の 場合と異なり $164 \mathrm{~cm}^{-1}$ のピーク強度が著しく低下している。 $\mathrm{C}_{30}$ と $\mathrm{G}_{30}$ は同一条件下においては DNA 負イオン照射量が 等しいと考えられるため、内包された DNAによる RBM 領域でのスペクトル変化は、塩基種の電気的特性によるも
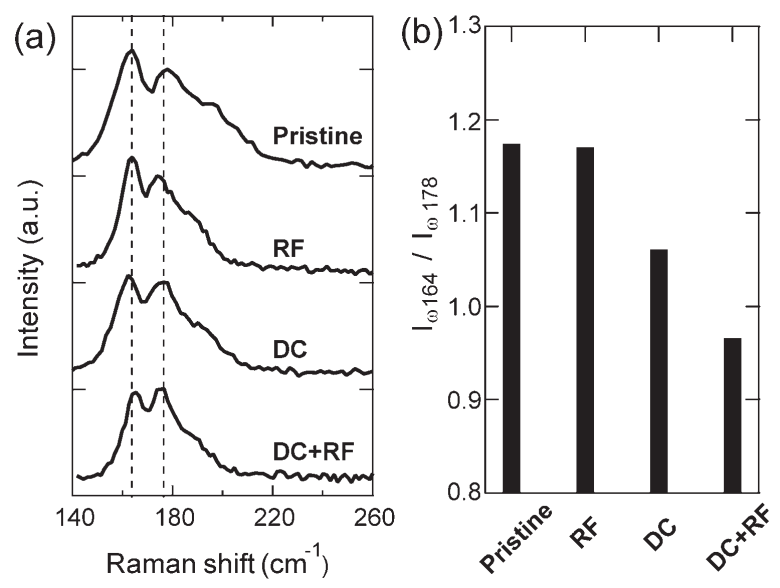

Fig. 3 (a) Raman spectra of SWNTs after DNA ion irradiation as functions of applied electric fields for $A_{15}$. (b) Intensity ratio of Raman spectrum peaks at $164 \mathrm{~cm}^{-1}$ and $178 \mathrm{~cm}^{-1}$. The excitation wavelength of laser is $488 \mathrm{~nm}$ and spot size of the laser is about $1 \mu \mathrm{m}^{2}$. $V_{\mathrm{DC}}=10 \mathrm{~V}, V_{\mathrm{RF}}=250 \mathrm{~V}, t=10 \mathrm{~min}$.

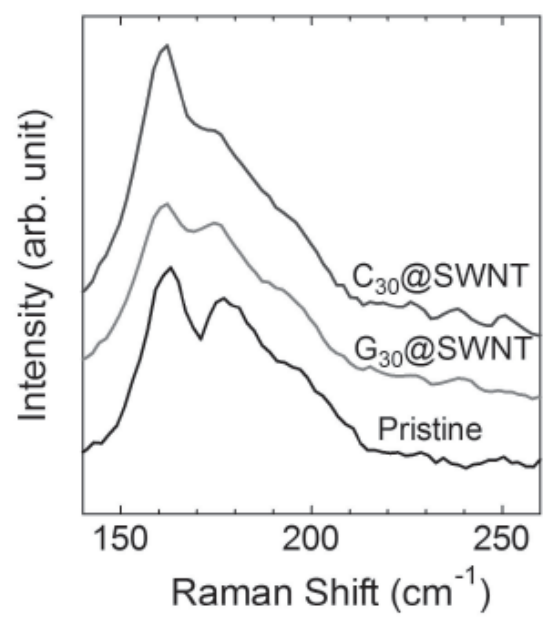

Fig. 4 Raman spectra of SWNT in the region of radial breathing mode after DNA encapsulation with the base sequence as a parameter. The excitation wavelength of the laser is $488 \mathrm{~nm}$. $V_{\mathrm{DC}}=10 \mathrm{~V}, t=10 \mathrm{~min}$.

のだと考えられる。グアニンの電子ドナー性を考慮すれば DNA と SWNT 間で電荷移動が行われていることが示唆さ れる。

図 5 に透過型電子顕微鏡（TEM）によって観察した DNA 負イオン照射後の (a) SWNT 像及び (b) DWNT 像を示 す。サンプルはDNAイオン照射後に純水で洗浄し、その 後エタノール中で超音波処理をした後に観察を行った。こ こでは、30 塩基で構成されている長さ $10 \mathrm{~nm}$ 程度の $\mathrm{A}_{30}$ 及 び $\mathrm{C}_{30}$ を用いている。図 5(a) では SWNT 内部に 1 次元構造 物質が内包されていることが分かる。上下の図は同じ写真 であり、下図では内包物質を黒線で示している。この物質 の長さは用いた DNA である $\mathrm{A}_{30}(\sim 10 \mathrm{~nm})$ とほぼ同一で 


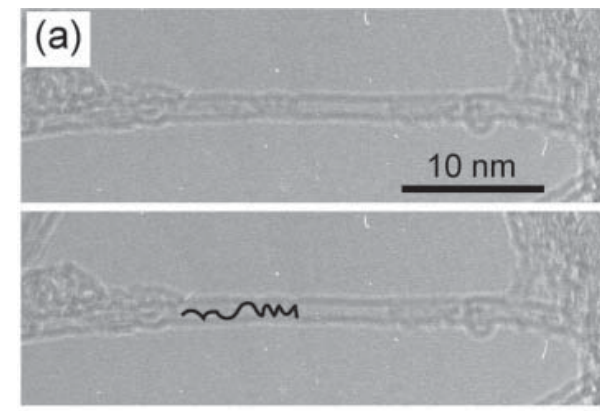

(b)

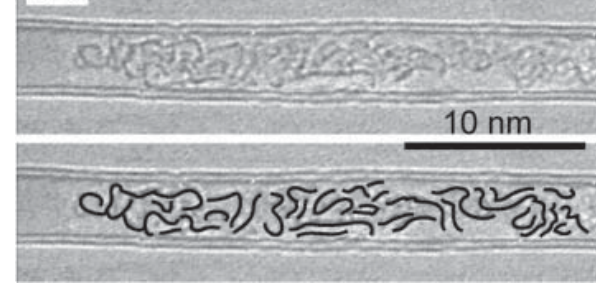

Fig. 5 TEM images of (a) $A_{30}$ encapsulated SWNT and (b) $\mathrm{C}_{30}$ encapsulated DWNT. The black lines in images indicate encapsulated materials.

あるため、SWNT 内部にDNA が内包した像観察に初めて 成功したと言える。

この SWNT に内包されたDNAの立体構造を詳細に観察 すると、SWNT 内部でらせん状構造をとっていることがわ かる。このような立体配置は塩基配列によるものではなく、 DNAの鎖長に依存していると考えられる。DNAの立体構 造に関与する SWNT との相互作用については幾つかの報告 があるが ${ }^{18)}$ 、全て SWNT の外壁と DNA の相互作用につい て議論されている。しかし、SWNT を構成する炭素のグラ ファイト構造と DNA 分子の関係は、本研究のような内包 した場合においても適用が可能であると考えられる。DNA は親水性のリン酸骨格とそれに付随した疎水性の塩基部分 からなり、一方で SWNT を構成するグラファイトは疎水性 である。この両者が接近したとき、互いの疎水性部分同士 の相互作用が強く働き、DNA の塩基部分が SWNT の内壁 側を向いて内包していると考えることができる。さらに、 DNA と SWNT の相互作用で重要なのは ある。 て安定に配置することである。DNA と SWNTにおいては、 それぞれ塩基とグラファイト格子が $\pi$ 電子を持っているの で、疎水性部分同士が向き合ったときにこれらは $\pi$ スッ キングすることで安定化するものと考えられる。つまり、 DNA が SWNT 内部に内包された場合、塩基と内壁グラファ イト格子は互いに疎水性であるためお互い向き合うように 配置し、さらには スタッキングによって安定した状態に あると考えている。

一方、SWNTよりも直径の太いDWNTにDNA負イオン を照射した場合には [図 5(b)]、非常に多数の DNA が密集

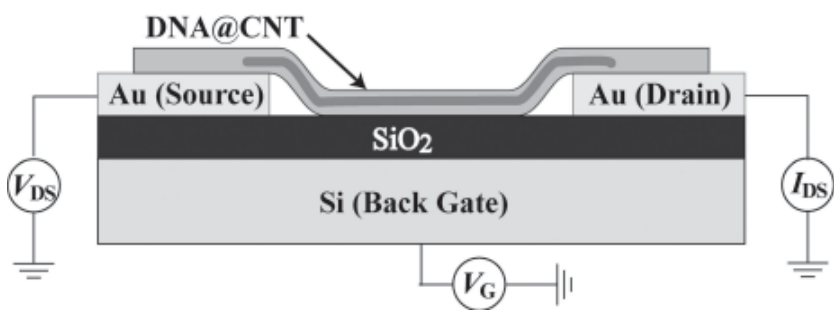

Fig. 6 Schematic of field effect transistor configuration using DNA encapsulated CNT.

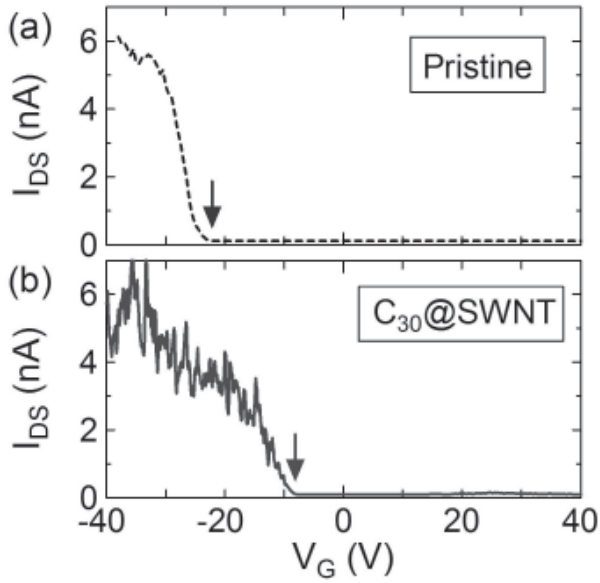

Fig. 7 Source-drain current $\left(I_{\mathrm{DS}}\right)$ vs gate voltage $\left(V_{\mathrm{G}}\right)$ characteristics measured with source-drain bias voltage $V_{\mathrm{DS}}=1 \mathrm{~V}$ at room temperature for (a) pristine SWNT (dotted line), and (b) $\mathrm{C}_{30}$ encapsulated SWNT (solid line).

して内包されているのが分かる。またDWNT の場合には、 直流電場のみでも十分にDNA が内包されており、内直径 が太い場合には高周波電場による DNAの伸長作用なしで も内包されることが明らかとなった ${ }^{19)}$ 。

これらのDNA 負イオンの動的挙動制御によって形成し た DNA 内包 CNT は、その特異的な電気的・光学的特性に よりナノバイオエレクトロニクスデバイスとしての応用が 期待されている。この新規な電気的・光学的特性が期待で きるDNA を内包したCNT を、図 6 に示すような電界効果 トランジスタ（FET）のチャネルとしてソースードレイン 間に架橋し、ゲート電圧 $V_{\mathrm{G}}$ 及びソース - ドレイン電圧 $V_{\mathrm{DS}}$ を変化させ、ソースードレイン電流 $I_{\mathrm{DS}}$ を測定することで、 その特性を調べた。

図 7 に DNA 内包 SWNT で作製したFETの電気（伝達） 特性を示す。DNA 照射前の Pristine SWNT［図 7(a)］は、 $\mathrm{V}_{\mathrm{G}}$ が負の值で $\mathrm{I}_{\mathrm{DS}}$ が上昇する $\mathrm{p}$ 型半導体特性を示しており、 一方、シトシン $\left(\mathrm{C}_{30}\right)$ を内包したSWNT [図 7(b) ] は、その $\mathrm{p}$ 型の半導体特性が強まっている。これは、SWNTからシ トシンへの電荷移動が生じ、SWNT が正孔リッチ状態にな 
(a)
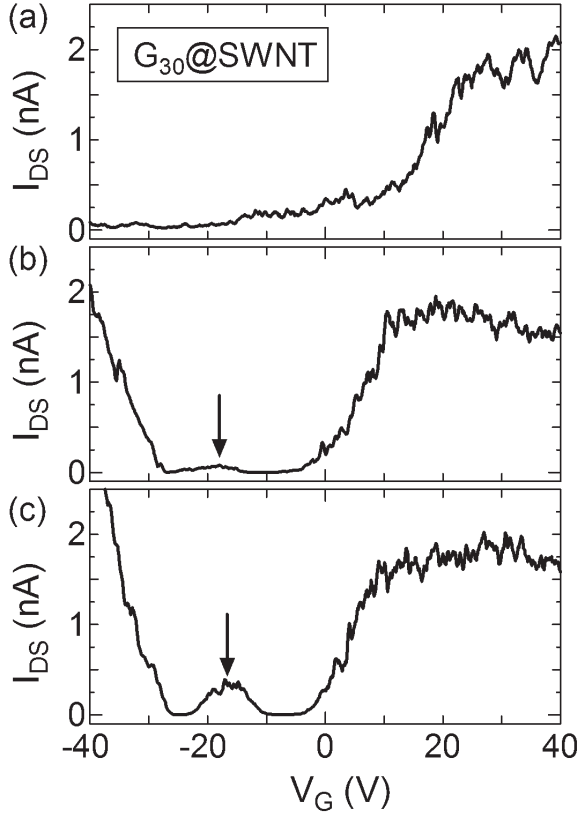

Fig. 8 Source-drain current $\left(I_{\mathrm{DS}}\right)$ vs gate voltage $\left(V_{\mathrm{G}}\right)$ characteristics at room temperature for $\mathrm{G}_{30}$ encapsulated SWNT.

ることで $\mathrm{p}$ 型半導体特性が強まったためと考えられる。

これらの結果に対して、グアニン $\left(\mathrm{G}_{30}\right)$ を内包した SWNT は図 8(a)に示すように全く反対の、 $\mathrm{V}_{\mathrm{G}}$ が正の值で $\mathrm{I}_{\mathrm{DS}}$ が増 加する $\mathrm{n}$ 型の電気特性を示すことが観測された。ここでは、 シトシンの場合とは反対に、グアニンから SWNT へ電荷移 動が生じ、SWNT が電子リッチ状態になり、 $\mathrm{n}$ 型半導体特 性に変化したと考えられる ${ }^{20)}$ 。

一方、同様の DNA 負イオン照射条件に扔いて、図 8(b)、 (c) に示すように、 $\mathrm{V}_{\mathrm{G}}$ が正の值とともに負の值でも $\mathrm{I}_{\mathrm{DS}}$ が増 加する電気特性が得られ、さらにその場合に $\mathrm{V}_{\mathrm{G}}=-20 \mathrm{~V}$ 近傍で新たなピークが観測されることが分かった。これは、 DNA の伸長度や SWNT の配向度等に差異が生じることで DNA の内包効率が変化し、SWNT を $\mathrm{n}$ 型半導体特性に変化 させるグアニンが部分的に SWNT に内包されることによっ て、内包されていない $\mathrm{p}$ 型半導体特性領域との間で $\mathrm{pn}$ 接 合が形成されるために生じることが明らかとなった。この 現象は、アルカリ金属 - ハロゲン原子内包 SWNT の pn 接 合 ${ }^{21)}$ で得られた結果とも一致している。

これらの DNA と SWNT との電荷移動は、DNA の塩基 と SWNT のイオン化ポテンシャル（酸化還元電位）の違い によって生じたものと考えられる。この電気特性の変化を 理解するために、カーボンナノチューブと DNA の塩基の イオン化ポテンシャルを紫外光電子分光装置を用いて測定 した。その結果、図 9 に示すようにグアニン $\left(\mathrm{G}_{30}\right)$ のイオ ン化ポテンシャルがシトシン $\left(\mathrm{C}_{30}\right)$ に比べて $0.2 \mathrm{eV}$ 程度小 さいことが明らかとなった。この結果は、グアニンが 4 種
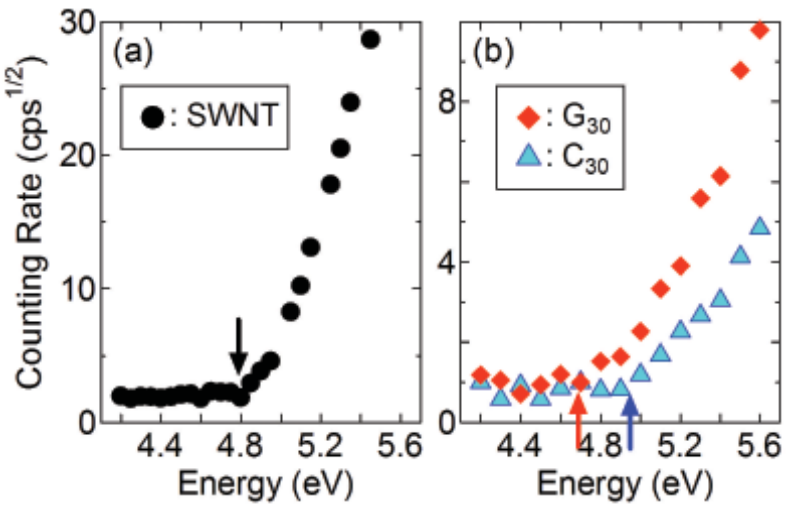

Fig. 9 Ultraviolet photoemission (UP) spectra of (a) SWNT and (b) $\mathrm{C}_{30}$ (triangles) and $\mathrm{G}_{30}$ (diamonds) at room temperature. The arrows show the highest occupied molecular orbital (HOMO) level, which corresponds to the ionization potential. (a)

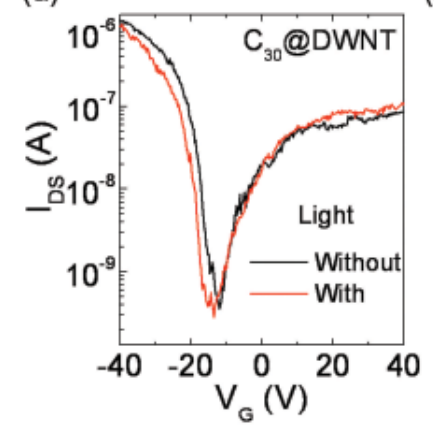

(b)

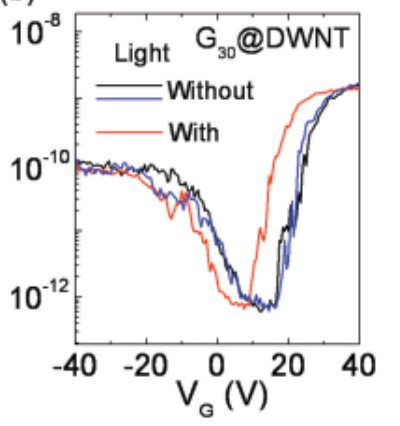

Fig. $10 I_{\mathrm{DS}}-V_{\mathrm{G}}$ characteristics of (a) $\mathrm{C}_{30} @ \mathrm{DWNT}$ and (b) $\mathrm{G}_{30} @ \mathrm{DWNT}$ measured with illumination by 400nm UV light (red curve) and without light (blue and black curves).

の塩基の中で最も低い酸化電位を示し、シトシンは比較的 高い酸化電位を示す結果 ${ }^{22}$ と同様の傾向を示している。さ らに興味深いことは、SWNT のイオン化ポテンシャルがグ アニンとシトシンの中間に存在し、その結果、グアニンは SWNT に電子を供給し、シトシンはSWNT より電子を受け 取ることで、それぞれ電子ドナー及びアクセプタとして機 能し、SWNT の電気特性に扔ける $\mathrm{n}$ 型発現及び $\mathrm{p}$ 型強化に 至ったものと考えられる。このように塩基の種類によって CNT の電気特性を制御でき、塩基の組み合わせによって pn 接合が形成できることを実証した。

これらの DNA 内包 CNT に抏いては、DNA 及びCNTが それぞれ光を吸収する特性を持っており、吸収した光に よって分子内の電子が励起されることで、電気特性が 変化 すると考元られる ${ }^{23)}$ 。DNA 内包 CNT の電気特性に対する 光照射の効果を調べた結果を図 10 に示す。ここでは、内 直径が大きく DNA の内包率が比較的大きい DWNT を使用 した結果について述べる。DNA が内包された DWNT に対 
して $400 \mathrm{~nm}$ の光を照射することによって、シトシンとグ アニンのどちらの場合にも、その電圧－電流特性が光照射 前 (黒線) と比較して $\mathrm{n}$ 型特性を助長する方向（ $V_{\mathrm{G}}$ が負の 方向）にシフトする (赤線) ことを世界で初めて観測した。 これは、光照射により励起されたDNAの電子がCNTに移 動することにより引き起こされるためであり、特にグアニ ンは光照射に敏感に反応し、励起されて移動する電子量が 多いため、そのシフト量が大きくなったと考えられる。さ らに、光照射を停止すると電気特性が光照射前の状態に戻 り (青線)、可逆的な特性を示すことが明らかとなっており、 この結果は、有機半導体としての DNA 内包 CNT が光スイッ チとして応用でき、ナノバイオ光デバイスとして有望な材 料であることを示している。

\section{5. 結論}

大気圧下の DNA 水溶液を「電解質プラズマ」と捉え、 溶液中におけるDNA負イオン照射によってDNA 内包 CNTの創製に成功した。DNA 負イオン照射及びCNTへの 内包は直流及び高周波電場強度と照射時間によって制御可 能であることが明らかとなった。また、CNT 内部に内包し た DNA 分子は CNT の直径によって立体構造が変化するこ とがわかった。

さらに、この電解質プラズマを用いて、塩基配列を制御 したDNA を CNT へ照射・内包することで、CNTの電気的、 光学的特性を制御することが可能となり、これらは新たな ナノバイオ有機半導体として、バイオセンサ、光スイッチ ングデバイス、量子効果デバイス、有機太陽電池等への応 用が期待されている。

\section{謝 辞}

本研究における共同研究者の田路和幸教授、岡田健博士、 廣津佑氏に心より感謝申し上げます。

\section{引用文献}

1) D. Porath, A. Bezryadin, S. Vries, and C. Dekker: Nature, 403 (2000) 635-638.

2) K. H. Yoo, D. H. Ha, J. O. Lee, J. W. Park, J. Kim, H. Y. Lee, T. Kawai, and H. T. Choi: Phys. Rev. Lett., 87 (2001) 198102-1-4.

3) R.G. Endres, D. L. Cox, and R. R. P. Singh: Rev. Mod. Phys., 76 (2004) 195-214.
4) H. Cai, X. Cao, Y. Jiang, P. He, and Y. Fang: Anal. Bioanal. Chem., 375 (2003) 287-293.

5) Y. F. Li, T. Kaneko, and R. Hatakeyama: Appl. Phys. Lett., 96 (2010) 023104-1-3.

6) R. Hatakeyama, T. Kaneko, W. Oohara, Y. F. Li, T. Kato, K. Baba, and J. Shishido: Plasma Sources Sci. Technol., 17 (2008) 024009-111 .

7) N. Sato, T. Mieno, T. Hirata, Y. Yagi, R. Hatakeyama, and S. Iizuka: Phys. Plasmas, 1 (1994) 3480-3484.

8) T. Hirata, R. Hatakeyama, T. Mieno, and N. Sato: J. Vacuum Sci. Technol. A, 14 (1996) 615-618.

9) G. -H. Jeong, R. Hatakeyama, T. Hirata, K. Tohji, K. Motomiya, T. Yaguchi, and Y. Kawazoe: Chem. Commun., (2003) 152-153.

10) G. -H. Jeong, A. A. Farajian, R. Hatakeyama, T. Hirata, T. Yaguchi, K. Tohji, H. Mizuseki, and Y. Kawazoe: Phys. Rev. B, 68 (2003) 075410-1-6.

11) G. -H. Jeong, R. Hatakeyama, T. Hirata, K. Tohji, K. Motomiya, N. Sato, and Y. Kawazoe: Appl. Phys. Lett., 79 (2001) 4213-1-3.

12) P. Debye and E. Huckel: Phisikalische Zeeitschrift, 24 (1923) 185206.

13) T. Kaneko, T. Okada, and R. Hatakeyama: Contrib. Plasma Phys., 47 (2007) 57-63.

14) M. Washizu and O. Kurosawa: IEEE Trans. Ind. Appl., 26 (1990) 1165-1172.

15) T. Okada, T. Kaneko, R. Hatakeyama, and K. Tohji: Chem. Phys. Lett., 417 (2006) 288-292.

16) T. Okada, T. Kaneko, and R. Hatakeyama: Jpn. J. Appl. Phys., 45 (2006) 8335-8339.

17) J. W. G. Wildoer, L. C. Venema, A. G. Rinzler, R. E. Smalley, and C. Dekker: Nature, 391 (1998) 59-62.

18) M. Zheng, A. Jagota, M. S. Strano, A. P. Santos, P. Barone, S. G. Chou, B. A. Diner, M. S. Dressselhaus, R. S. Mclean, G. B. Onoa, G. G. Samsonidze, E. D. Semke, M. Usrey, D. J. Walls: Science, 302 (2003) 1545-1548.

19) Y. F. Li, T. Kaneko, and R. Hatakeyama: Small, 6 (2010) 729-732.

20) T. Kaneko and R. Hatakeyama: Appl. Phys. Express, 2 (2009) 127001-1-3.

21) T. Kato, R. Hatakeyama, J. Shishido, W. Oohara, and K. Tohji: Appl. Phys. Lett., 95 (2009) 083109-1-3.

22) D. Kato, N. Sekioka, A. Ueda, R. Kurita, S. Hirono, K. Suzuki, and O. Niwa: J. Am. Chem. Soc. 130 (2008) 3716-3717.

23) Y. F. Li, T. Kaneko, Y. Hirotsu, and R. Hatakeyama: Small, 6 (2010) 27-30. 